\title{
Zero tolerance of prescriptivism?
}

This issue of ET has a special focus on prescriptivism and the English language, guest edited by Ingrid Tieken-Boon van Ostade and Rajend Mesthrie. The main theme of the six papers selected concerns the rise of ideas about 'good' and 'bad' language: they dissect seminal works that promoted a view that there was something wrong with the way English was often used, and assess the impact of these works upon the use of the language today.

The papers originate in a workshop on Normative Linguistics organized by Ingrid Tieken-Boon van Ostade at ISLE, the newly founded International Society for the Linguistics of English - whose first conference of 2008 was covered in a report in ET99. The title of the conference was 'The Linguistics of English: Setting the Agenda'. During the workshop, which was enthusiastically attended throughout the day, ten papers were presented and discussed. Members of the workshop panel included Anita Auer (University of Leiden), Joan Beal (University of Sheffield), Charlotte Brewer (University of Oxford), Kate Burridge (Monash University), Ulrich Busse (Martin Luther University Halle-Wittenberg), David Crystal (University of Wales, Bangor), Victorina González-Díaz (University of Liverpool), Jenny McManus (University of Liverpool), Geoffrey Pullum (University of Edinburgh), Anne Schröder (Martin Luther University HalleWittenberg), Nuria Yáñez-Bouza (University of Manchester) and Ingrid Tieken-Boon van Ostade (University of Leiden). Of the papers presented, one of them has already appeared in print: the panel had the privilege of being given to read an advance version of David Crystal's introduction to the Oxford University Press reprint, as part of their World Classics Series, of Fowler's Modern English Usage, which appeared in September 2009.

Of the remaining papers, six were revised and selected for this issue of ET. They deal with a variety of aspects relating to prescriptivism: linguistic taboo and purism in reactions to programmes on language in the Australian media (Kate Burridge), the rise of the usage guide (Ingrid Tieken-Boon van Ostade), prescriptivism in the Oxford English Dictionary (Charlotte Brewer), prescriptivism in America with reference to Strunk \& White (Geoffrey Pullum), the reception and current status of Fowler's Modern English Usage (Ulrich Busse \& Anne Schröder), and popular prescriptivism in Britain today with main focus on 'the grocer's apostrophe' with reference to prescriptivists like Lynne Truss and her 'zero tolerance' approach to the humble grocer (Joan Beal). The majority of the papers, in one way or other, deal with Fowler, which suggests that his work has recently and deservedly become a topic of serious linguistic research. With these papers we hope to show that, like any other branch of linguistics, Normative Linguistics deserves its place on the agenda of the linguistics of English. Studying normative linguistics will help account for the enormous popularity of Lynne Truss's Eats, Shoots and Leaves, which according to the blurb in the first trade paperback printing of 2006 'has sold more than three million copies worldwide' - but also for the complete lack of interest in the publication of the Dutch adaptation of the book by Wim Daniëls in 2004. Normative Linguistics will also offer ways of trying to understand the alleged but large-scale lack of actual influence of normative grammar, since its rise and enormous popularity in the eighteenth century, on usage today.

Another contribution to this issue comes from our regular columnist, Alexander Tulloch, who takes us into the semantic and etymological world of elections and electioneering. As he wryly infers from the form and meanings of the words from classical times to the present, the more things change, the more they stay the same ....

Ingrid Tieken-Boon van Ostade, Rajend Mesthrie \& the remaining ET editors

The editorial policy of English Today is to provide a focus or forum for all sorts of news and opinion from around the world. The points of view of individual writers are as a consequence their own, and do not reflect the opinion of the editorial board. In addition, wherever feasible, ET generally leaves unchanged the orthography (normally British or American) and the usage of individual contributors, although the editorial style of the journal itself is that of Cambridge University Press. 